\title{
A Descriptive Analysis on Entrepreneurial Intention among Engineering Technology Students
}

\author{
Salwah Che Mat ${ }^{1}$, Siti Mistima Maat ${ }^{2} \&$ Norhatta Mohd $^{3}$ \\ ${ }^{1}$ Universiti Kuala Lumpur Malaysia France Institute, Selangor, Malaysia \\ ${ }^{2}$ Faculty of Education, Universiti Kebangsaan Malaysia, Selangor, Malaysia \\ ${ }^{3}$ Universiti Kuala Lumpur Malaysian Institute of Information Technology, Kuala Lumpur, Malaysia \\ Correspondence: Salwah Che Mat, Universiti Kuala Lumpur Malaysia France Institute, Section 14, Jalan Teras \\ Jernang, 43650, Bandar Baru Bangi, Selangor, Malaysia. Tel: 60-17-336-7477. E-mail: salwah@unikl.edu.my
}

Received: June 15, 2015 Accepted: July 13, 2015 Online Published: August 18, 2015

doi:10.5539/ass.v11n24p286 URL: http://dx.doi.org/10.5539/ass.v11n24p286

\begin{abstract}
The study of entrepreneurship and the factors that lead people to become entrepreneurs have developed into an interesting topic for research. The purpose of this study is to investigate the factors that determine the entrepreneurial intention among engineering technology students in Universiti Kuala Lumpur Malaysia France Institute. 63 engineering technology students were selected to be the study sample. Samples were drawn using the random sampling technique and a self administered survey. The data were analyzed using descriptive statistics. The study has an implication to the university and the government in developing and planning for entrepreneurship activities, program and education to increase the entrepreneurial intention among engineering technology students.
\end{abstract}

Keyword: entrepreneurship, entrepreneurial intention, engineering technology

\section{Introduction}

Entrepreneurship has been known to be the main catalyst for economic growth of a country. In the era of globalization, entrepreneurship and entrepreneurs have been declared to be highly important. A country's competitive force will be defined by the entrepreneurial spirit and innovativeness owned by its nation. The government has been giving a special attention to the development of entrepreneurs by providing a lot of programmes and strategies through various government agencies.

Therefore investigating the factors that determine the entrepreneurial intentions of students is a crucial issue in entrepreneurship research.

This study aimed to examine the factors that determined Universiti Kuala Lumpur Malaysia France Institute (UniKl MFI) students' entrepreneurial intention. The study focused on the personality factors and environmental factors. Personality factors include need for achievement (McClelland, 1976) and self-efficacy (Bandura, 1986), while environmental factors include factors such as social networks, capital and information access (Mazzarol et al., 1999). Similar studies have been conducted to investigate students' entrepreneurial intention in several countries (Kristiansen \& Indarti, 2004; Ismail et al., 2009; Indarti et al., 2010).

\section{Literature Review}

Entrepreneurship has been an interesting topic discussed not only by the economists, sociologists but also psychologists. Various researches by those disciplined have enhanced and developed the theories of entrepreneurship. There are various definitions of entrepreneur and entrepreneurship.

Among the earliest is Schumpeter (1934), who defined entrepreneurship as a firm that operates and implements a combination of new activities such as product development, marketing, resources of raw materials, manufacturing approach and new organizational structure.

Entrepreneurship is a dynamic process of vision, change, and creation. It requires an application of energy and passion towards the creation and implementation of new ideas and creative solutions. The essential ingredients include the willingness to take calculated risks - in term of time, equity, or career; the ability to formulate an effective venture team; the creative skills to marshal needed resources; the fundamental skill of building a solid 
business plan; and finally, the vision to recognize opportunity where others see chaos, contradiction and confusion (Kuratko, 2009, p. 5).

Krueger and Carsrud (1993) defined entrepreneurial intention as individual commitment to start a new business. Bird and Jellinek (1988) defined entrepreneurial intention as the level of cognitive awareness which direct to set up a new business. Bird and Jellinek clarified that intention is a thinking situation consisting of concentration, experience and individual behavior towards a specific goal or certain behavior. It is important to understand the overall process of entrepreneurial intention because the intention is usually related in establishing a new business (Bird \& Jellinek, 1988; Krueger \& Carsrud, 1993).

The current research focus mainly on examining predictors of entrepreneurial intention from the demographic, personality and instrument readiness factors. Demographic factor include gender, age, education and past experience. Personality factor include need for achievement, locus of control and self-efficacy, and instrument readiness factor include access to capital, information and social network. Each factor will be discussed in detail in the next section.

\subsection{Demography and Individual Background}

Many researchers have examined the impact of demographic factors on entrepreneurial behavior. In this study we measure the impact of age, gender, education and working experience as predictor towards the students' intention to start a new business. Findings from Sinha (1996) showed that the majority of successful entrepreneurs in India are relatively young. Reynolds et al., (2000) found that the most active entrepreneurs in Western countries are individuals aged 25-44 years. Next, Mazzarol et al. (1999) found that females were generally less likely to be founders of new business than males. Nwankwo et al. (2012) supported the findings by concluding that males engage in entrepreneurial activities more that the females because the orientation is that male posses personal characteristics that predispose them to aggressively act, assessments, risk taking and creative attitudes. On the other hand, a study by Lee (1997) found that female entrepreneurs have a higher level of need for achievement as an entrepreneur.

As stated by Krueger, Reilly and Carsrud (2000) entrepreneurship does not happen by chance as it can be developed and encouraged through the function of education. Entrepreneurship education is defined as the process of providing individuals with the concepts and skills to recognize opportunities that others have overlooked and to have the insight and self-esteem to act where others have hesitated. Sinha (1996) also revealed that educational background is important in nurturing entrepreneurial intention as well as business success. Previous studies indicated past experience is regraded as a predictor of entrepreneurial intention. Individual with working experience tends to have higher entrepreneurial intention compared to those without (Kolveried, 1996). Similarly, Zhang (2013) found that working or past experience will likely influence individual perception towards having the intention to become an entrepreneur.

\subsection{Personality Factors}

In this study we focused on three factors related to personality as the core predictors of entrepreneurial intention: need for achievement (McClelland, 1976), locus of control (Kristiansen and Indarti, 2004) and self-efficacy (Bandura, 1997). McClelland (1976) introduced the concept of need for achievement (N-Ach) as one of psychological motivation. N-Ach referre to an individual's desire for significant accomplishment, mastering of skills, control, or high standards. McClelland called the individuals with high achievement needs as gamblers. They set challenging targets for themselves and they took the deliberate risk to achieve those set targets. Such individuals looked for innovative ways of performing job. They perceived achievement of goals as a reward, and valued it more than a financial reward. The characteristics listed in McClelland suit very well with the characteristics of entrepreneurs.

The concept of locus of control refers to a generalized belief that a person can or cannot control his or her own destiny. Gifford (2003), in a study explained that the influence of locus of control on perceptual alertness is the ability to see potential opportunities in the environment. He concluded a person who has an internal locus of control has greater amounts of perceptual alertness which leads pontaneous learning. The last factor of self-efficacy is the measure of one's own ability to complete tasks and reach goals. Bandura (1997) defined self-efficacy as the subjective conviction that one is capable of action in a given situation, of coping with a task. Unlike other personality traits of entrepreneurship which are relatively static, self-efficiency is affected by contextual factors such as education and past-experiences (Holleabeck \& Hall, 2004).

\subsection{Instrumental Readiness}

Accesses to capital, information and social network are considered to have an impact on entrepreneurial 
intention. These three factors are grouped as 'instrumental readiness'. Capital is the foundation in any new businesses. Capital access is every important for start-up companies. The entrepreneurs have a limited source of financing normally using their own savings or borrowed from family and friends as it is quite difficult for them to get the capital from external sources.

Access to information has been considered as one of the critical factors for the development and growth of a venture. Singh and Krishna (1994) stated that strong intention to access information is one of the main characters of Indian entrepreneurs. Information seeking can include searching for projects, opportunities, sources of financing, market study etc. Entrepreneurs not only interact with people in the organization but also with others outside the organization. The social network is a business tool that plays a significant role in the success of the entrepreneurs (Azahari et al., 2013) while networking is important for entrepreneurs to gain access to either tangible or intangible resources directly or indirectly for example to reduce risks and cost as well as to provide access to business ideas, capital and information.

\section{Methodology}

Table 1. Respondents' profile

\begin{tabular}{|c|c|c|c|c|}
\hline & & \multicolumn{2}{|c|}{ Program } & \multirow{2}{*}{ Total } \\
\hline & & MTM & WQI & \\
\hline \multirow{2}{*}{ Gender } & Male & 29 & 31 & 60 \\
\hline & Female & 3 & 0 & 3 \\
\hline Total & & 32 & 31 & 63 \\
\hline
\end{tabular}

Using a survey method, 63 engineering technology students from Universiti Kuala Lumpur Malaysia France Institute were chosen as the respondents. There were 60 male students and 3 female students from two different programs. Out of 63 students, 32 were from Machine Technology and Maintenance (MTM) and 31 students were from Welding and Quality Inspection (WQI). The details of the respondents are shown in Table 1.

The data were collected by 63 items-instrument of the Entrepreneurial Intention (EI) which has eight constructs of past experience of 9 items, attitude towards entrepreneurship of 7 items, perceived and support barriers of 13 items, locus of control of 14 items, needs for achievement of 5 items, entrepreneurial intention of 9 items, instrumental readiness of 3 items and subjective norms of 3 items. A 5 point Likert scale was used in collecting the data ranging from " 1 " as "Strongly Disagree" to " 5 " as "Strongly Agree". The instrument is adapted based on Kristiansen and Indarti, (2004).

Reliability of the instrument was established through Cronbach alpha coefficient at the adequate value of 0.884 . The lowest value was 0.639 for past experience and the highest was 0.781 for entrepreneurial intention. The values of the Cronbach alpha for all the constructs were more than acceptable value of 0.5 (Nunally, 1978) as shown in Table 2.

Table 2. Reliability of all constructs

\begin{tabular}{ccc}
\hline Construct & Number of items & Cronbach's Alpha \\
\hline Past experience & 9 & 0.639 \\
Attitude towards entrepreneurship & 7 & 0.668 \\
Locus of control & 14 & 0.642 \\
Needs for achievement & 5 & 0.756 \\
Entrepreneurial intention & 9 & 0.781 \\
Instrumental readiness & 3 & 0.778 \\
\hline
\end{tabular}




\section{Findings and Discussion}

Table 3. Age of respondents

\begin{tabular}{ccccc}
\hline & \multicolumn{2}{c}{ Program } & Total \\
\hline Age & MTM & WQI & 56 \\
& $21-25$ years & 28 & 28 & 7 \\
\hline
\end{tabular}

Descriptive statistics and selected inferential statistics were used to analyse the data. Table 3 shows the age profile of the respondents and the entrepreneurship subjects taken by the respondents. Based on the total of 63 respondents, 56 age between 21-25 years old and only 7 age between $26-23$ years old.

Table 4. Entrepreneurship subjects taken by respondents

\begin{tabular}{cccc}
\hline & \multicolumn{2}{c}{ Program } & \\
& MTM & WQI & 11 \\
\hline Techopreneurship only & 11 & 0 & 31 \\
Innovation Management only & 14 & 17 & 21 \\
Technoprenuership \& Innovation Management & 7 & 31 & 63 \\
Total & 32 & 31 & \\
\hline
\end{tabular}

UniKL has made it compulsory for all degree students to take two entrepreneurship subjects to graduate. The two subjects offered by the university are Technopreneurship and Innovation Management. Table 4 shows the number of respondents who have taken the entrepreneurship subjects. It was found that all respondents have taken at least one of the entrepreneurship subjects. 11 respondents have taken Technopreneurship, 31 have taken Innovation Management and 21 of the respondents have taken both subjects.

Table 5. Mean and standard deviation of all constructs

\begin{tabular}{ccc}
\hline Construct & Mean & Std. Deviation \\
\hline Past experience & 1.7275 & .13707 \\
Locus of control & 3.6043 & .47046 \\
Needs for achievement & 3.9270 & .62041 \\
Entrepreneurial intention & 3.7372 & .62131 \\
Instrumental readiness & 3.3439 & .87573 \\
\hline
\end{tabular}

Based on Table 5, it was found that the highest mean was for needs for achievement and past experience has the lowest mean value. Needs for achievement recorded the highest mean because it is the drive factors to face challenges for success. High achievers will always have high intention to be the best. Past experience has the lowest mean value due to lack of working experience among these students.

A summary of responses to the main items of the questionnaire from MTM and WQI respondents is shown in Table 6 .

Respondents moderately agreed that need for achievement is an important factor towards entrepreneurial intention. Both programs stated "to improve on past work performance" has the highest mean $(\mathrm{MTM}=4.38$, $\mathrm{WQI}=4.06$ ), followed by 'seek added responsibilities in job assigned' (MTM=4.28, WQI=4.00). The lowest mean is 'do well in difficult tasks relating to study and work' (MTM=4.03, WQI=3.61). 
Table 6. Summary of responses

\begin{tabular}{|c|c|c|c|c|}
\hline \multirow{3}{*}{ Variables } & \multirow{2}{*}{\multicolumn{2}{|c|}{$\begin{array}{l}\text { MTM } \\
\mathrm{N}=32\end{array}$}} & \multirow{2}{*}{\multicolumn{2}{|c|}{$\begin{array}{l}\text { WQI } \\
\mathrm{N}=31\end{array}$}} \\
\hline & & & & \\
\hline & Mean & SD & Mean & SD \\
\hline \multicolumn{5}{|l|}{ Need for Achievement } \\
\hline $\begin{array}{l}\text { I will do very well in difficult tasks relating to my } \\
\text { study and my work. }\end{array}$ & 4.03 & 0.93 & 3.61 & 0.92 \\
\hline I will try to improve on past work performance. & 4.38 & 0.66 & 4.06 & 0.81 \\
\hline $\begin{array}{l}\text { I will seek added responsibilities in the job assigned } \\
\text { to me. }\end{array}$ & 4.28 & 0.68 & 4.00 & 0.77 \\
\hline \multicolumn{5}{|l|}{ Locus of Control } \\
\hline Persistence and hard work usually lead to success. & 4.17 & 1.08 & 4.26 & 0.77 \\
\hline I do not really believe in luck & 3.53 & 1.34 & 2.94 & 1.09 \\
\hline If I do not succeed on a task, I will give up. & 2.59 & 1.39 & 2.48 & 1.36 \\
\hline \multicolumn{5}{|l|}{ Self Efficacy } \\
\hline I have leadership skills to be an entrepreneur & 3.94 & 0.91 & 3.68 & 1.01 \\
\hline I have the mental maturity to be an entrepreneur. & 3.75 & 0.92 & 3.52 & 0.96 \\
\hline \multicolumn{5}{|l|}{ Entrepreneurial Intention } \\
\hline I will choose a career as an entrepreneur. & 3.5 & 0.95 & 3.16 & 1.16 \\
\hline $\begin{array}{l}\text { I will choose to be an employee in a company/an } \\
\text { organization. }\end{array}$ & 3.47 & 1.14 & 3.48 & 1.12 \\
\hline $\begin{array}{l}\text { I prefer to be an entrepreneur rather than to be an } \\
\text { employee in a company. }\end{array}$ & 3.84 & 0.99 & 3.52 & 1.21 \\
\hline \multicolumn{5}{|l|}{ Instrumental Readiness } \\
\hline I have access to capital to start a new venture & 3.22 & 1.10 & 3.10 & 0.94 \\
\hline $\begin{array}{l}\text { I have good social networks that can be utilized } \\
\text { when I decide to be an entrepreneur. }\end{array}$ & 3.53 & 1.11 & 3.13 & 1.06 \\
\hline $\begin{array}{l}\text { I have access to supporting information to start to be } \\
\text { an entrepreneur. }\end{array}$ & 3.69 & 1.06 & 3.39 & 1.02 \\
\hline
\end{tabular}

The second factor is locus of control. Overall respondents agreed that persistence and hard work will be the main drive to success. The mean recorded by WQI (4.26) is higher than MTM (4.17). The result may be influence by the nature of the program that required the students to work hard to be successful in their study. All respondents do not believe in luck and they do not easily give up.

On self-efficacy, the results indicate respondents moderately agreed that self-efficacy have the influence towards entrepreneurial intention. The highest mean is on the statement 'I have leadership skills to be an entrepreneur' $(\mathrm{MTM}=3.94, \mathrm{WQI}=3.68)$ and followed by mental maturity $(\mathrm{MTM}=3.75, \mathrm{WQI}=3.52)$.

Students are moderately inclined about venturing into their own business in the future with the mean results between 3.84 and 3.16. Entrepreneurial intentions among MTM respondents are higher than WQI respondents. Based on two statements; 'I prefer to be an entrepreneur rather than to be an employee in a company' and 'I will choose a career as an entrepreneur' both recorded higher mean on MTM respondents with 3.84 and 3.5 respectively. WQI respondents set higher mean (3.48) than MTM on choosing to be an employee in a company.

In the context of instruments readiness, results of the study shows that the respondents moderately agreed that instruments readiness encourage the entrepreneurial intention with mean between 3.69 and 3.10. The highest mean is access to information ( $\mathrm{MTM}=3.69, \mathrm{WQI}=3.39$ ), followed by access to social network (MTM=3.53, $\mathrm{WQI}=3.13)$. The lowest mean is access to capital (MTM=3.22, WQI $=3.10)$. 


\section{Conclusion}

It has been accepted that the country is depending on the students as the source of entrepreneurship. This generation is the future leader, the future anchor of the country thus this study provides some significance. This research investigates the factors that contribute to entrepreneurial intention among UniKL MFI students. Primary data were collected by distributing questionnaires to 63 students from 2 different programs. The following conclusion can be drawn from the study. To begin with, this study has shown that generally the engineering technology students of UniKL MFI have the intention to become entrepreneurs after completion of their studies. For personality traits, the most important factor that drive entrepreneurial intention is need for achievement, followed by self-efficacy and lastly locus of control. The students agreed that for instrument readiness, access to information is the most important, followed by social network and access to capital. The results of this study indicate that entrepreneurial intention did exist among the UniKL MFI students but they must be equipped with necessary knowledge, skills and experience to start their own business. The university need to nurture the entrepreneurial intention by involving all students in entrepreneurship activities in the campus. Teaching and learning process in the classroom is not enough to encourage the students to choose entrepreneurship as a career choice. Hands on experience is more important to expose the students with the reality and reward of entrepreneurship.

The respondents of this study were limited to two programs from UniKL MFI. Thus the results will not generalize the entrepreneurial intention among engineering technology students in UniKL. Future research can be conducted to study the correlations among the variables and can be extended to all UniKL campuses.

\section{Acknowledgements}

The authors would like to thank the Universiti Kuala Lumpur on Short Term Research Grant (STRG), the lecturers and respondents involved in the survey.

\section{References}

Azahari, J., Abd Razak, M. Y., Mohd Hazli, M. R., Hamidon, K., Jimisiah, J., Mohd Fauzi, Z. A., ... Zawiah, A. M. (2013). Technopreneurship. Kuala Lumpur: Oxford Fajar.

Bandura, A. (1997). Self-efficacy: the exercise of control. New York: W.H. Freeman \& Company.

Bird, B. \& Jellinek, M. (1988). The Operation of Entrepreneurial Intentions. Entrepreneurship Theory and Practice, winter, 21-29.

Gifford, S. (2003). Risk and uncertainty. In Z. Acs, \& D. Audretsch (Eds.), The Handbook of Entrepreneurship Research (pp. 37-54). New York: Kluwer.

Hollenbeck, G., \& Hall, D. T. (2004). Self-confidence and leader performance. Organizational Dynamic, 33(3), 254-269. http://dx.doi.org/10.1016/j.orgdyn.2004.06.003

Indarti, N., Rostiani, R., \& Nastiti, T. (2010). Underlying Factors of Entrepreneurial Intentions among Asian Students. The South East Asian Journal of Management, 4(2), 143-160.

Ismail, M., Khalid, S. A., Othman, M., Jusoff, K., Abdul Rahman, N., Mohammed, K. M., \& Shekh, R. Z. (2009). Entrepreneurial Intention among Malaysian Undergraduates. International Journal of Business and Management, 4(10), 54-60. http://dx.doi.org/10.5539/ijbm.v4n10p54

Kolvereid, L. (1996). Prediction of Employment Status Choice Intentions. Entrepreneurship Theory and Practice, 21(1), 47-57.

Kristiansen, S., \& Indarti, N. (2004). Entrepreneurial Intention among Indonesian and Norwegian Students. Journal of Enterprising Culture, 12(1), 55-78. http://dx.doi.org/10.1142/s021849580400004x

Krueger, N. F., \& Carsrud, A. L. (1993). Entrepreneurial Intentions: Applying the Theory of Planned Behavior. Entrepreneurship \& Regional Development, 5(4), 315-330.

Krueger, N. F., Reilly, M. D., \& Carsrud, A. L. (2000). Competing models of entrepreneurial intentions. Journal of Business Venturing, 15(5-6), 411-432. http://dx.doi.org/10.1016/s0883-9026(98)00033-0

Kuratko, D. F. (2009). Entrepreneurship-theory, process and practice (8th ed.). South Western: Cengage Learning.

Lee, J. (1997). The Motivation of Women Entrepreneurs in Singapore. International Journal of Entrepreneurial Behaviour and Research, 3(2), 93-110. http://dx.doi.org/10.1108/13552559710175392

Mazzarol, T., Volery, T., Doss, N., \& Thein, V. (1999). Factors Influencing Small Business Start-ups. 
International Journal of Entrepreneurial Behaviour and Research, 5(2), 48-63. http://dx.doi.org/10.1108/13552559910274499

McClelland's Theory of Needs. (n. d.). Retrieved June 21, 2013, from Management Study Guide, http://www.managementstudyguide.com/mcclellands-theory-of-needs.htm

Nunally, J. C. (1993). Psychometric theory. New York: Mc Graw Hill.

Nwankwo, B. E., Marire, M. I., Kanu, G. C., Balogun, S. K., \& Uhiara, A. C. (2012). Gender-Role Orientation And Self Efficacy As Correlates Of Entrepreneurship Intention. European Journal of Business and Social Sciences, , 1(6), 9-26.

Reynolds, P. D., Hay, M., Bygrave, W. D., Camp, S. M., \& Aution, E. (2000). Global Entrepreneurship Monitor, Executive Report. Babson College, Kauffman Center for Entrepreneurial Leadership and London Business School.

Schumpeter, J. A. (1934). The Theory of Economic Development: An Inquiry into Profits, Capital, Credit, Interest, and the Business Cycle. University of Illinois at Urbana-Champaign's Academy for Entrepreneurial Leadership Historical Research Reference in Entrepreneurship. Retrieved from http://ssrn.com/abstract=1496199

Singh, K. A., \& Krishna, K. V. S. M. (1994). Agricultural Entrepreneurship: The Concept and Evidence. Journal of Entrepreneurship, 3(1), 97-111. http://dx.doi.org/10.1177/097135579400300106

Sinha, T. N. (1996). Human Factors in Entrepreneurship Effectiveness. Journal of Entrepreneurship, 5(1), 23-29. http://dx.doi.org/10.1177/097135579600500102

Zhang, Y., Duysters, G., \& Cloodt, M. (2013). The role of entrepreneurship education as a predictor of university students' entrepreneurial intention. International Entrepreneurship and Management Journal, 10(3), 623-641. http://dx.doi.org/10.1007/s11365-012-0246-z

\section{Copyrights}

Copyright for this article is retained by the author(s), with first publication rights granted to the journal.

This is an open-access article distributed under the terms and conditions of the Creative Commons Attribution license (http://creativecommons.org/licenses/by/3.0/). 